\title{
Comparative study on two rapid and sensitive methods for quantitative determination of tenoxicam in tablets
}

\author{
Anil Kumar Singh, Pedro López García, Fábio Pereira Gomes, Erika Rosa Maria Kedor- \\ Hackmann, Maria Inês Rocha Miritello Santoro*
}

Departamento de Farmácia, Faculdade de Ciências Farmacêuticas, Universidade de São Paulo

*Correspondence:

M. I. R. M. Santoro

Departamento de Farmácia

Faculdade de Ciências Farmacêuticas

- USP

Caixa Postal 66355

05389-970 - São Paulo - SP, Brasil

E-mail: ines@usp.br
Tenoxicam, a piroxicam analogue, is an NSAID (Non-Steroid Antinflamatory Drug). It is used in the symptomatic management of musculoskeletal and joint disorders such as osteoarthritis and rheumatoid arthritis, and also in the short-term management of softtissue injury. Its quantitative determination in pharmaceutical formulations is important to guarantee the desired therapeutic effects. The objective of this research was to develop, validate and compare spectrophotometric and chromatographic methods in the quantitative determination of tenoxicam in tablet preparations. In this work, tablets containing $20.0 \mathrm{mg}$ of tenoxicam from different origins were analyzed. The spectrophotometric method was validated using $0.1 \mathrm{~mol} / \mathrm{L} \mathrm{NaOH}$ as solvent and a signal at $368 \mathrm{~nm}$ was taken. The HPLC method was validated using Synergi Hydro-RP ${ }^{\circledR}$ C18 column $(250 x 4.6 \mathrm{~mm}, 4 \mu \mathrm{m})$. The mobile phase was constituted of methanol-water $(61: 39 \mathrm{v} / \mathrm{v})$ with pH adjusted to 2.5 with formic acid, at a flow rate of $1.0 \mathrm{~mL} / \mathrm{min}$. UV detection was made at $375 \mathrm{~nm}$. All analyses were performed with a column temperature of $25^{\circ} \mathrm{C} \pm 1$. The calibration curves were linear over a concentration range from 4.0-24.0 $\mu \mathrm{g} / \mathrm{mL}$ with a correlation coefficient better than 0.9999. The detection limit (DL) and quantitation limit $(Q L)$ were $0.25 \mu \mathrm{g} / \mathrm{mL}$ and $0.90 \mu \mathrm{g} / \mathrm{mL}$ for $U V$ method and $0.35 \mu \mathrm{g} / \mathrm{mL}$ and $1.20 \mu \mathrm{g} / \mathrm{mL}$ for HPLC method respectively. The intra-day and inter-day precision expressed as $R S D$ were below $2 \%$ for both methods. The mean recovery of tenoxicam was found to be in the range of 98.5-101.25\% for UV method and 99.01-101.93\% for HPLC method. The UV and HPLC methods were found to be rapid, precise and accurate. Statistically there was no significant difference between proposed UV spectrophotometric and HPLC methods.
Uniterms:

- Tenoxicam/quantitative determination

- Spectrophotometry

- High performance liquid chromatography 


\section{INTRODUCTION}

Tenoxicam (Figure 1) is an enolic acid derivative that inhibits high levels of COX-2 at the sites of inflammation and thus has anti-inflammatory, analgesic, and antipyretic activity. This nonselective COX inhibitor is extensively used in the treatment of rheumatoid arthritis and osteoarthritis. Chemically, tenoxicam is 4-hydroxy-2methyl- $N$-2-pyridinyl-2H-thieno(2,3-e)-1,2-thiazine-3carboxamide 1,1-dioxide with pKa 4.50 and 3.73 .

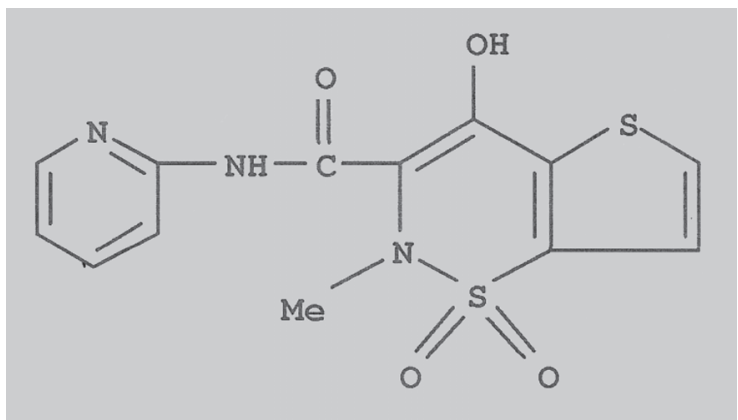

FIGURE 1 - Chemical structure of tenoxicam.

To guarantee the pharmacological activity and assure quality of pharmaceutical products it is important to quantify them with accuracy and precision (UNITED States Pharmacopeia, 2005). Several analytical methods are described in recent literature such as mass spectrometric (McKinney et al., 2004), spectrofluorometric (Taha et al., 2002; Barary et al., 2004), potentiometric (El-Ries et al., 2003), polarographic (Atkopar and Tuncel, 1996), infrared spectrophotometric (Atay and Dincol, 1997) [7], coulometric (Nikolic et al., 1993), spectrophotometric (Amin, 2002; Garcia et al., 1999; El-Ries, 1998; Yener, Topaloglu, 1992; El Walily et al., 1997), derivative spectrophotometric (Taha et al., 2003) and high performance liquid chromatographic techniques (Hye et al., 2005; Sultan, et al., 2005; Taha et al., 2004; Bartsch et al., 2002; Abdel-Hamid, 2000; JosephCharles and Bertucat, 1999; Radhofer-Welte, Dittrich, 1998; Walily et al., 1997; Tracqui et al., 1995; Mason and Hobbs, 1995; Munera-Jaramillo, Botero-Garces, 1993; Carlucci et al., 1992; Dixon et al., 1984).

The spectrophotometric method and HPLC with UV detection are analytical techniques widely used in analytical laboratories. The HPLC methods described in literature involve sample pre-treatment and troublesome buffers components in the mobile phase. The hyphenated LC-MS detection makes these methods available to only a few. On the other hand a majority of described spectrophotometric methods involves sample pre-treatment or use of derivation technique due to their application in the determination of the active compound in the presence of its degradation products. The objective of this study was to develop rapid and economical methods that could be applied for quantitative determination of tenoxicam in quality control laboratories. The supporting data on repeatability, recovery, linearity, specificity and limits of detection and quantitation prove precision, accuracy, selectivity and sensitivity of the proposed methods.

\section{EXPERIMENTAL}

\section{Chemicals}

The standard used was the pure compound (99.61\%) and was used without any further purification. The samples (A and B) were tablets containing $20 \mathrm{mg}$ of tenoxicam. The placebo was prepared in laboratory based on the excipients present in tablet samples, namely microcrystalline cellulose, starch, polyvidone, sodium croscarmelose, colloidal silicon dioxide, macrogol 400, talc and titanium dioxide. The standard, samples and excipients were obtained from local pharmaceutical industries. HPLC grade methanol and sodium hydroxide $(\mathrm{NaOH})$ were obtained from Merck (Darmstadt, Germany). High purity water was prepared by using Waters Milli- ${ }^{\circledR}$ plus purification system.

\section{Equipment}

A LC system consisted of a solvent delivery system, an auto-injector fitted with $20 \mu \mathrm{L}$ loop, an online degasification system, a column thermostat oven and an UV/VIS photodiode array detector. The output signal was monitored and integrated using CLASS VP ${ }^{\circledR}$ software (Shimadzu Corporation, Japan).

The UV method was performed on a UV-VIS spectrophotometer, UV-1601 (Shimadzu Corporation, Japan). The output signal was monitored and processed using UVPC v3.91 Personal Spectroscopy Software (Shimadzu Scientific Instruments Inc. Japan).

\section{Spectrophotometric condition}

The UV method was performed with $0.1 \mathrm{~mol} / \mathrm{L}$ $\mathrm{NaOH}$ solution as medium. UV detections were made at $368 \mathrm{~nm}$, using $1.0 \mathrm{~cm}$ quartz cell and with wavelength scanning rate of $370 \mathrm{~nm} / \mathrm{min}(250-450 \mathrm{~nm})$.

\section{Chromatographic condition}

Analytical conditions were standardized through the LC system using Synergi Hydro-RP ${ }^{\circledR}$ C 18 column (250x4.6 mm, 
$4 \mu \mathrm{m})$. The mobile phase was constituted of methanol-water $(61: 39 \mathrm{v} / \mathrm{v})$ with $\mathrm{pH}$ adjusted to 2.5 with formic acid, at a flow rate of $1.0 \mathrm{~mL} / \mathrm{min}$. UV detection was made at $375 \mathrm{~nm}$. The volume of injection was fixed at $20 \mu \mathrm{L}$. All analyses were done with a column temperature of $25^{\circ} \mathrm{C} \pm 1$. The mobile phase was prepared fresh each day, vacuum-filtered through a $0.45 \mu \mathrm{m}$ Millipore ${ }^{\circledR}(\mathrm{HV})$ hydrophilic membrane.

\section{Calibration curve (UV and HPLC)}

The calibration curve for tenoxicam was constructed by separate analyses ( 3 times) of six different standards solutions of tenoxicam containing 4.0 to $24.0 \mu \mathrm{g} / \mathrm{mL}$. The solutions with desired concentrations were obtained by diluting the stock solution with $0.1 \mathrm{~mol} / \mathrm{L} \mathrm{NaOH}$ (UV method) and with mobile phase (HPLC method). The calibration curve was constructed by plotting mean response versus respective tenoxicam concentration.

\section{Standard solution for determination of inter and intra-day repeatability (UV and HPLC)}

Amount of tenoxicam standard, equivalent to $12.0 \mathrm{mg}$ was accurately weighed and transferred to a $25 \mathrm{~mL}$ volumetric flask. Approximately $20 \mathrm{~mL}$ of $0.1 \mathrm{~mol} / \mathrm{L} \mathrm{NaOH}$ was added and the content of the flask was sonicated for $10 \mathrm{~min}$. The solution in the flask was diluted to volume with the same solvent. Appropriate dilutions were made with $0.1 \mathrm{~mol} / \mathrm{L} \mathrm{NaOH}$ to obtain solutions containing $12.0 \mu \mathrm{g} / \mathrm{mL}$ of tenoxicam. For HPLC method, similar procedure was adopted by using mobile phase as diluting solvent, to obtain solution containing $12.0 \mu \mathrm{g} / \mathrm{mL}$ of tenoxicam.

\section{Sample solution for determination of inter and intra- day repeatability (UV and HPLC)}

For the UV method, twenty tablets were individually weighed and were triturated to obtain homogeneous mass. Amount of sample mass, equivalent to $12.0 \mathrm{mg}$ of tenoxicam, was accurately weighed and transferred to a $25 \mathrm{~mL}$ volumetric flask. Approximately $20 \mathrm{~mL}$ of $0.1 \mathrm{~mol} / \mathrm{L} \mathrm{NaOH}$ were added and the content of the flask was sonicated for $10 \mathrm{~min}$. The volume of the flask was completed with the same solvent and the final solution was filtered through Whatmann no. 1 paper filter. Appropriate dilutions were obtained by transferring aliquots of the above solution to volumetric flasks. The final sample solutions were obtained containing approximately $12.0 \mu \mathrm{g} / \mathrm{mL}$ of tenoxicam. For HPLC method, similar procedure was adopted by using mobile phase as diluting solvent, to obtain final sample solutions containing approximately $12.0 \mu \mathrm{g} / \mathrm{mL}$ of tenoxicam.

\section{Standard and sample solutions for recovery test (UV and HPLC)}

For UV method, standard and sample solutions were prepared separately as described above to obtain solution containing $40.0 \mu \mathrm{g} / \mathrm{mL}$ of tenoxicam. Method accuracy was assessed by determining the agreement between the difference in the measured analyte concentrations of the fortified and unfortified sample and the known amount of analyte added to fortify the sample. Solution of standard containing $40.0 \mu \mathrm{g} / \mathrm{mL}$ of tenoxicam, at three different levels, was used to fortify the sample solutions. The final concentrations of these fortified solutions were 8.0, 12.0 and $16.0 \mu \mathrm{g} / \mathrm{mL}$ of tenoxicam (Table III). The theoretical concentrations of added standard in these solutions are 4.0, 8.0 and $12.0 \mu \mathrm{g} / \mathrm{mL}$ of tenoxicam, respectively.

For HPLC method, the recovery test was performed with standard and sample solutions containing $40.0 \mu \mathrm{g} / \mathrm{mL}$ of tenoxicam. The final concentrations of these fortified solutions were $8.0,12.0$ and $16.0 \mu \mathrm{g} / \mathrm{mL}$ of tenoxicam (Table III). All standard and sample solutions were filtered through $0.45 \mu \mathrm{m}$, Millipore ${ }^{\circledR}$ (Millex HV) hydrophilic membrane, before injection into the system.

\section{RESULTS AND DISCUSSION}

\section{Quantitative determination of tenoxicam (UV)}

The direct UV method allows a rapid and economical quantification of tenoxicam in pharmaceutical preparations without time-consuming sample pre-treatment steps. Absorption spectra of the tenoxicam are shown in Figure 2. UV detection was carried out at $368 \mathrm{~nm}$ for the quantification of tenoxicam.

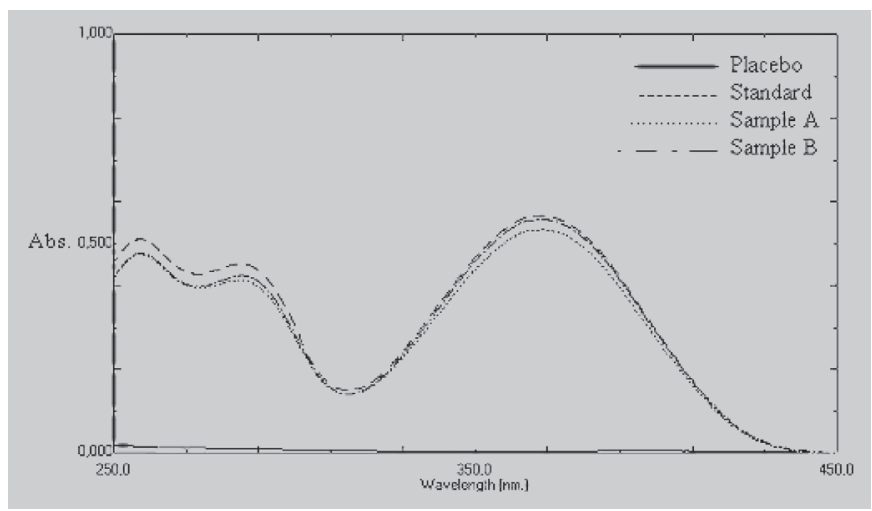

FIGURE 2 - Ultraviolet absorption spectra in $0.1 \mathrm{NaOH}$ : (A) placebo, (B) $12.0 \mu \mathrm{g} / \mathrm{mL}$ tenoxicam standard, (C) $12.0 \mu \mathrm{g} / \mathrm{mL}$ tenoxicam (sample A) and (D) $12.0 \mu \mathrm{g} / \mathrm{mL}$ tenoxicam (sample B). 


\section{Quantitative determination of tenoxicam (HPLC)}

To develop a suitable and robust LC method for the determination of tenoxicam different mobile phases and columns were employed to achieve the efficient separation

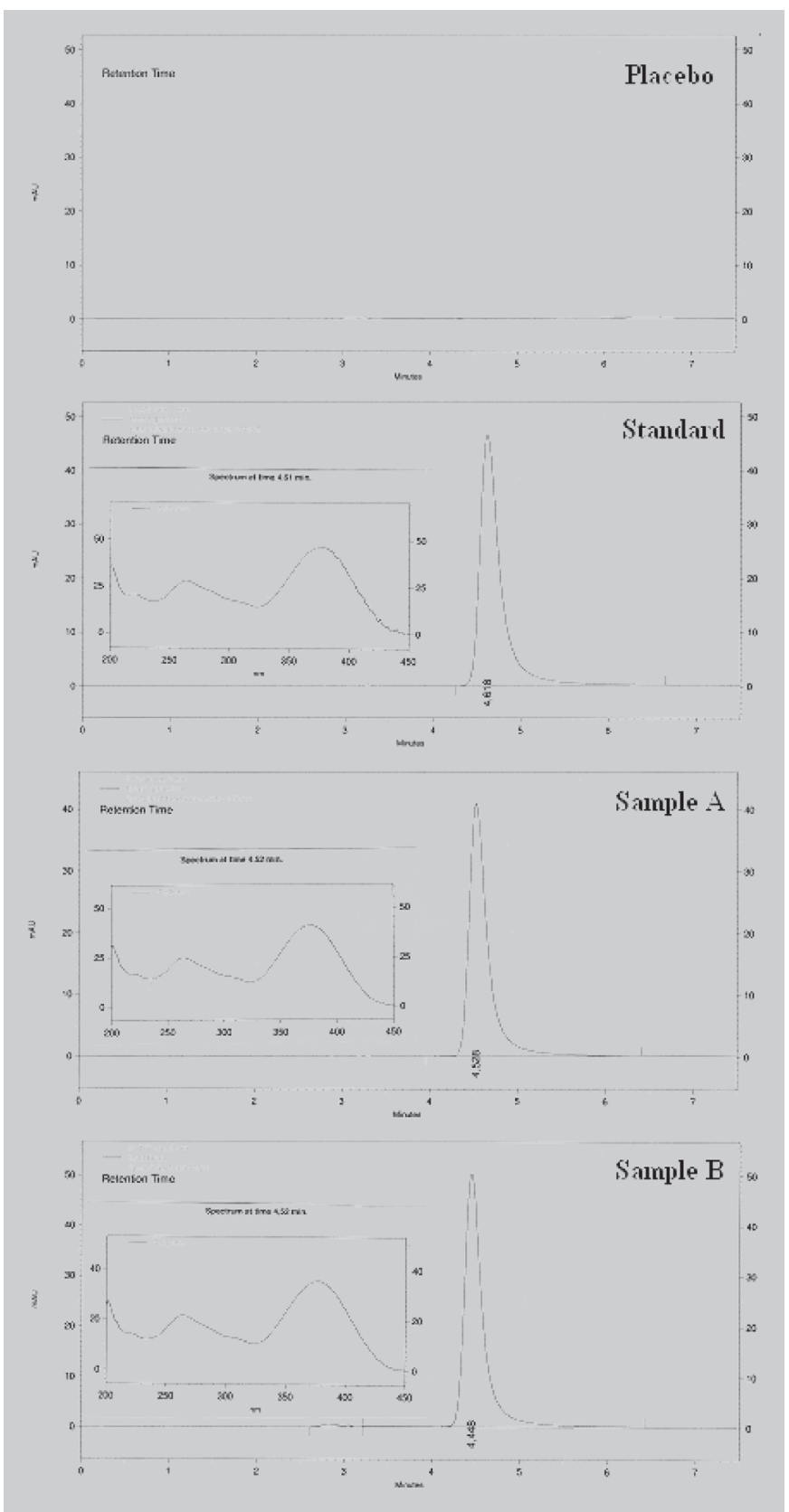

FIGURE 3 - Chromatograms of placebo, standard and sample, concentration equivalent to $12.0 \mu \mathrm{g} / \mathrm{mL}, 20 \mu \mathrm{L}$ injected. Chromatographic conditions: mobile phase: methanol-water $(61: 39 \mathrm{v} / \mathrm{v}), \mathrm{pH}$ adjusted to 2.5 with formic acid, flow rate $1.0 \mathrm{~mL} / \mathrm{min}$ and $\mathrm{UV}$ detection at $375 \mathrm{~nm}$; Synergi Hydro-RP ${ }^{\circledR} \mathrm{C} 18$ column $(250 \times 4.6 \mathrm{~mm}, 4 \mu \mathrm{m})$, oven temperature $\left(24^{\circ} \mathrm{C}\right)$. and resolution. Due to well known problems associated with buffers our intention was to obtain rapid chromatographic separation with good peak symmetry without using a buffer solution. Attempts with traditional reverse phase columns presented poor peak symmetry and tailing problem. Most of the separation methods in literature overcame these problems by use of buffers in mobile phase. The proposed method was able to selectively separate tenoxicam in a short chromatographic run ( $4.5 \mathrm{~min}$ ). The tenoxicam can be identified by matching the UV spectrum and the retention times with standards. The chromatograms are shown in Figure 3.

\section{Linearity (UV and HPLC)}

Linearity was checked by analyzing standard solutions at six different concentration levels ranging from 4.0 to $24.0 \mu \mathrm{g} / \mathrm{mL}$. The correlation coefficient was found to be greater than 0.9999 for both the UV and HPLC methods, indicating good linearity. The analytical curve values of slope, intercept and correlation coefficient for tenoxicam are presented in Table I.

TABLE I - Linear regression data in the analysis of tenoxicam using UV and HPLC methods

\begin{tabular}{lcc}
\hline PARAMETERS & UV & HPLC \\
\hline Concentration range $(\mathrm{mg} / \mathrm{mL})$ & $4.0-24.0$ & $4.0-24.0$ \\
Regression equation & $\begin{array}{l}y=0.0441 x \\
+0.0117\end{array}$ & $\begin{array}{c}y=67466 x \\
+15115\end{array}$ \\
Correlation coefficient $(\mathrm{r})$ & 0.9999 & 0.9999 \\
$\mathrm{DL}(\mathrm{mg} / \mathrm{mL})$ & 0.25 & 0.35 \\
$\mathrm{QL}(\mathrm{mg} / \mathrm{mL})$ & 0.90 & 1.20 \\
\hline $\mathrm{DL}=$ Detection limit & & \\
$\mathrm{QL}=$ Quantitation limit & &
\end{tabular}

\section{Precision (UV and HPLC)}

The method precision was evaluated by inter and intra-day repeatability. The intra-day repeatability was done by analyzing a single concentration of samples in replicate (10 times) and is expressed in terms of RSD with respective confidence interval. For UV method ten working solutions $(12.0 \mu \mathrm{g} / \mathrm{mL})$ were prepared from same stock solution, while for HPLC method single working solution $(12.0 \mu \mathrm{g} / \mathrm{mL})$ was injected ten times. For both methods, RSD values were found to be well below $1.52 \%$, indicating good intra-day repeatability (Table II). 
The inter-day repeatability was determined by analyzing sample solutions prepared from same stock solution on three consecutive days, at the same concentration level. The inter-day repeatability is expressed in terms of RSD values with respective confidence interval. The RSD values were well below $1.10 \%$ indicates a good intermediate precision for both methods (Table II).

\section{Accuracy (UV and HPLC)}

Standard addition for fortification and recovery experiments were conducted to determine the accuracy of the present method for the quantification of tenoxicam. As per ICH guidelines the range of addition levels of impurities used in this study is $70-130 \%$ of the nominal concentration (mean concentration of curve) (International Conference on Harmonization, 1995). The accuracy of the method was checked at three concentration levels i.e. at 8.0,12.0 and $16.0 \mu \mathrm{g} / \mathrm{mL}$. Triplicate analyses were done with HPLC method and in case of UV method 10 determinations were made. For both methods, recovery \% calculations were made based on the amount of standard added to the sample solutions. The accuracy is expressed as percentage of standard recovered from sample matrix with corresponding RSD and confidence interval (AOAC International, 1990). The mean recovery of tenoxicam was found to be in the range of 98.5-101.25\% for UV method and 99.01-101.93 $\%$ for HPLC method. The recovery data is presented in Table III.

\section{Specificity (UV and HPLC)}

Specificity is the ability of the method to accurately measure the analyte response in the presence of all potential sample components (excipients). All related excipients were used to prepare placebo sample solution as described above and were analyzed using proposed methods. The results were compared with the analysis of a standard tenoxicam

TABLE II - Precision results and statistical data obtained in the determination of tenoxicam in pharmaceutical preparation

\begin{tabular}{lcccc}
\hline & & UV $^{*}$ & & HPLC* \\
& Sample A & Sample B & Sample A & Sample B \\
\hline Intra-day & & & $20.20 \pm 0.14$ & $19.73 \pm 0.15$ \\
\hline Day 1 & $19.80 \pm 0.03$ & $19.04 \pm 0.05$ & 0.99 & 1.07 \\
RSD & 0.25 & 0.37 & $20.38 \pm 0.12$ & $20.03 \pm 0.14$ \\
Day 2 & $19.91 \pm 0.21$ & $18.83 \pm 0.02$ & 0.80 & 0.99 \\
RSD & 1.48 & 0.18 & $20.86 \pm 0.23$ & $19.82 \pm 0.16$ \\
Day 3 & $20.35 \pm 0.21$ & $19.15 \pm 0.17$ & 1.52 & 1.11 \\
RSD & 1.49 & 1.27 & & $19.86 \pm 0.15$ \\
\hline Inter-day & & & $20.48 \pm 0.16$ & 1.06 \\
\hline
\end{tabular}

*mean of 10 determinations

TABLE III - Results obtained in the recovery of tenoxicam standard solution added to sample A and sample B analyzed by the proposed UV and HPLC methods

\begin{tabular}{|c|c|c|c|c|c|c|}
\hline \multirow{3}{*}{ Sample } & \multicolumn{3}{|c|}{ UV } & \multicolumn{3}{|c|}{ HPLC } \\
\hline & \multicolumn{2}{|c|}{ Amount (mg) } & \multirow{2}{*}{$\begin{array}{c}\text { Recovery } \\
(\%)\end{array}$} & \multicolumn{2}{|c|}{ Amount (mg) } & \multirow{2}{*}{$\begin{array}{c}\text { Recovery } \\
(\%)\end{array}$} \\
\hline & Added & Found & & Added & Found & \\
\hline \multirow[t]{3}{*}{ A } & 4.00 & 3.97 & $99.25 \pm 0.13$ & 4.00 & 3.98 & $99.55 \pm 0.48$ \\
\hline & 8.00 & 8.06 & $100.75 \pm 0.14$ & 8.00 & 7.96 & $99.51 \pm 2.00$ \\
\hline & 12.00 & 12.08 & $100.66 \pm 0.06$ & 12.00 & 12.23 & $101.93 \pm 0.49$ \\
\hline \multirow[t]{3}{*}{ B } & 4.00 & 3.90 & $98.50 \pm 0.33$ & 4.00 & 3.96 & $99.01 \pm 1.09$ \\
\hline & 8.00 & 8.10 & $101.25 \pm 0.69$ & 8.00 & 7.96 & $99.52 \pm 0.64$ \\
\hline & 12.00 & 11.94 & $99.50 \pm 0.25$ & 12.00 & 11.93 & $99.47 \pm 0.73$ \\
\hline
\end{tabular}


solution. No interference from excipients was observed in either of the proposed methods (Figure 2 and Figure 3).

\section{Detection Limit (DL) and Quantitation limit (QL)}

The DL and QL were determined for both HPLC and UV methods. The limits were determined based on the standard deviation amongst response and slope of the curve at lowest concentrations (International Conference on Harmonization, 1995). The obtained theoretical values for DL and QL were actually prepared and were cross checked by actual analysis using proposed methods. The DL and QL were $0.25 \mu \mathrm{g} / \mathrm{mL}$ and $0.90 \mu \mathrm{g} / \mathrm{mL}$ for UV method and $0.35 \mu \mathrm{g} / \mathrm{mL}$ and $1.20 \mu \mathrm{g} / \mathrm{mL}$ for HPLC methods respectively (Table I).

\section{Comparison between UV and HPLC method}

The proposed analytical methods were compared using statistical analysis. The $F$-test was applied to determine whether one population is more variable than another in relative standard deviations (repeatability). The obtained results were 1.20 and 1.36 , for sample $A$ and $B$, respectively, well below the tabulated value (3.18) at $95 \%$ confidence level. The $t$-test was applied to determine whether or not there is a statistically significant difference between the mean assay values of two proposed methods. The obtained results were 0.23 and 0.38 , for sample $A$ and $\mathrm{B}$, respectively, well below the tabled value (2.10) at $95 \%$ confidence level. The calculated $F$-values and $t$-values were found to be less than the critical values at $5 \%$ significance level (3.18 and 2.10 respectively).

\section{CONCLUSION}

The proposed methods for quantitative determination of tenoxicam in pharmaceutical formulation are efficient and sensitive. The studied excipients of the commercial sample analyzed did not interfere in the analysis, which proved the specificity of the method for these formulations. Thus, the use of the proposed methods in other type of formulations should be made after a previous selectivity study. The UV and HPLC methods were found to be simple, rapid, precise, accurate and sensitive. The statistical data prove that the two methods are equally precise and there is no significant difference between the proposed methods for assay determinations. Its advantages over other existing methods are its low-cost and non-polluting conditions. Either method can be used for routine quality control of tenoxicam in commercial samples.

\section{ACKNOWLEDGEMENTS}

We are indebted to FAPESP and CNPq for continuous financial support.

\section{RESUMO}

\section{Estudo comparativo de dois métodos rápidos e sensíveis para a determinação quantitativa de tenoxicam em comprimidos}

Tenoxicam, um análogo de piroxicam, é um AINE (Antiinflamatório Não-Esteróide). ë usado no tratamento sintomático de doenças musculoesqueléticas das juntas, tais como osteoartrite e artrite reumatóide, e, também, no tratamento de danos dos tecidos moles. Sua determinação quantitativa em formulações farmacêuticas é importante para garantir os efeitos terapêuticos desejados. O objetivo dessa pesquisa foi desenvolver, validar e comparar métodos espectrofotométrico e cromatográfico na determinação quantitativa de tenoxicam em comprimidos. Neste trabalho, comprimidos contendo 20,0 mg de tenoxicam de diferentes procedências foram analisados. O método espectrofotométrico foi validado utilizando-se $0,1 \mathrm{~mol} / \mathrm{L}$ de $\mathrm{NaOH}$ como solvente e se obteve sinal a 368 nm. O método por CLAE foi validado utilizando-se coluna Synergi Hydri-RP ${ }^{\circledR} C 18(250 x 4,6 \mathrm{~nm}, 4 \mu \mathrm{m})$. A fase móvel constitui-se de metanol-água (61:39v/v), com pH ajustado para 2,5 com ácido fórmico, e velocidade de fluxo de 1,0 mL/minuto. A detecção por UV foi efetuada a $375 \mathrm{~nm}$. Todas as análises foram realizadas com temperatura de coluna a $25^{\circ} \mathrm{C} \pm 1$. As curvas de calibração foram lineares na faixa de concentração de 4,0 a 24,0 $\mu \mathrm{g}$ / $m L$, comcoeficiente de correlação melhor que 0,9999. O limite de detecção $(L D)$ e o limite de quantificação $(L Q)$ foram $0,25 \mu \mathrm{g} / \mathrm{mL}$ e 0,90 $\mu \mathrm{g} / \mathrm{mL}$ e 1,20 $\mu \mathrm{g} / \mathrm{mL}$ por CLAE, respectivamente. A precisão intra e inter-dia, expressa como RSD, foi abaixo de $2 \%$ para ambos os métodos. A média de recuperação do tenoxicam ficou na faixa de 98,5 a 101,25\% para o método de UV, e 99,01 a 101,93, para a CLAE. Os métodos de UV e de CLAE mostraram-se rápidos, precisos e exatos. Estatisticamente, não se observou diferença significativa entre os métodos espectrofotométricos (UV) e CLAE.

UNITERMOS: Tenoxicam/determinação quantitativa. Espectrofotometria. Cromatografia a líquido de alta eficiência. 


\section{REFERENCES}

ABDEL-HAMID, M.E. LC-MS analysis of selected sulfurcontaining non-steroid anti-inflammatory agents: Applications to pharmaceutical products. J. Liq. Chromatogr. Relat. Technol.v.23, n.20, p.3095-3107, 2000.

AMIN,A.S. Spectrophotometric determination of piroxicam and tenoxicam in pharmaceutical formulations using alizarin. $J$. Pharm. Biomed. Anal., v.29, n.4, p.729-736, 2002.

AOAC INTERNATIONAL. Official Methods of Analysis. 15.ed. Arlington: AOAC INTERNATIONAL, 1990. p.xvii.

ATAY, O.; DINÇOL, F. Quantitative determination of tenoxicam by infrared spectrophotometry. Anal. Lett., v.30, n.9, p.1675-1684, 1997.

ATKOPAR, Z:; TUNÇEL, M. The polarographic determination of tenoxicam in the pharmaceutical preparations. Anal. Lett., v.29, n.13, p.2383-2397, 1996.

BARARY, M.H.; ABDEL-HAY, M.H.; SABRY, S.M.; BELAL, T.S. Spectrofluorimetric determination of 2aminopyridine as a potential impurity in piroxicam and tenoxicam within the pharmacopoeial limit. J. Pharm. Biomed. Anal., v.34, n.1, p.221-226, 2004.

BARTSCH, H.; EIPER, A.; KOPELENT-FRANK, H.; SAKKA, E. Selective assays for quantitation of tenoxicam in presence of its photodegradation products. J. Liq. Chromatogr. Relat. Technol., v.25, n.18, p.28212831, 2002.

CARLUCCI, G.; MAZZEO, P.; PALUMBO, G Determination of tenoxicam in human plasma using solid-phase extraction and high-performance liquid chromatography with ultraviolet detection. J. Liq. Chromatogr. Relat. Technol., v.15, n.4, p.683-695, 1992.

DIXON, J.S.; LOWE, J.R.; GALLOWAY, D.B. Rapid method for the determination of either piroxicam or tenoxicam in plasma using high-performance liquid chromatography. J. Chromatogr., A., v.310, n.2, p.455459, 1984.
EL WALILY, A.F.M.; BLAIH, S.M.; BARARY, M.H.; EL SAYED, M.A.; ABDINE, H.H.; EL KERSH, A.M. Simultaneous determination of tenoxicam and 2aminopyridine using derivative spectrophotometry and high-performance liquid chromatography. J. Pharm. Biomed. Anal., v.15, n.12, p.1923-1928, 1997.

EL-RIES, M.A. Spectrophotometric determination of piroxicam and tenoxicam in pharmaceutical preparations using uranyl acetate as a chromogenic agent. Anal. Lett., v.31, n.5, p.793-807, 1998.

EL-RIES, M.A.; MOHAMED, G.; KHALIL, S.; ELSHALL, M. Spectrophotometric and potentiometric determination of piroxicam and tenoxicam in pharmaceutical preparations. Chem. Pharm. Bull., v.51, n.1, p.6-10, 2003.

GARCIA, M.S.; SANCHEZ-PEDREÑO, C.; ALBERO, M.; GIMENEZ, M.J. Flow-injection spectrophotometric methods for the determination of tenoxicam. J. Pharm. Biomed. Anal., v.21, n.4, p.731-738, 1999.

HYE, Y.J.; HYE, W.L.; YOUNG, H.K.; DONG, W.J.; LEE, H.S. Simultaneous determination of piroxicam, meloxicam and tenoxicam in human plasma by liquid chromatography with tandem mass spectrometry. $J$. Chromatogr., B: Anal. Technol. Biomed. Life Sci., v.826, n.1/2, p.214-219, 2005.

INTERNATIONAL CONFERENCE ON HARMONIZATION(ICH). Text on validation of analytical procedure: methodology: Q2(R1), 2005. Disponível em: http://www.ich.org.. Acesso em: 24 jul. 2006.

JOSEPH-CHARLES, J.; BERTUCAT, M. J. Simultaneous high performance liquid chromatographic analysis of nonsteroidal anti-inflammatory oxicams in pharmaceutical preparations. J. Liq. Chromatogr. Relat. Technol., v.22, n.13, p.2009-2021, 1999.

MASON, J.L.; HOBBS, G.J. Simple method for the analysis of tenoxicam in human plasma using high-performance liquid chromatography. J. Chromatogr, B: Anal. Technol. Biomed. Life Sci., v.665, n.2, p.410-415, 1995.

MCKINNEY, A.R.; SUANN, C.J.; STENHOUSE,A.M. The detection of piroxicam, tenoxicam and their metabolites in equine urine by electrospray ionisation ion trap mass spectrometry. Rapid Commun. Mass Spectrom., v.18, n.19, p.2338-2342, 2004. 
MUNERA-JARAMILLO, M.I.; BOTERO-GARCES, S. Determination of tenoxicam in plasma by high-performance liquid chromatography. J. Chromatogr., B: Anal. Technol. Biomed. Life Sci., v.616, n.2, p.349-352, 1993.

NIKOLIC, K.; BOGAVAC, M.; ARSENIJEVIC, L. Coulometric determination of some antiinflammatory compounds. Farmaco, v.48, n.8, p.1131-1136, 1993.

RADHOFER-WELTE, S.; DITTRICH, P. Determination of the novel non-steroidal anti-inflammatory drug lornoxicam and its main metabolite in plasma and synovial fluid. J. Chromatogr, B: Anal. Technol. Biomed. Life Sci., v.707, n.1/2, p.151-159, 1998.

SULTAN, M.; STECHER, G.; STOEGGL, V.M.; BAKRY, R.; ZABORSKI, P.; HUCK, C.W.; EL KOUSY, N.M.; BONN, G.K. Sample pretreatment and determination of non steroidal anti-inflammatory drugs (NSAIDs) in pharmaceutical formulations and biological samples (blood, plasma, erythrocytes) by HPLC-UV-MS and $1 / 4 \mathrm{u}-$ HPLC. Curr. Med. Chem., v.12, n.5, p.573-588, 2005.

TAHA, E.A.; EL-ZANFALLY, E.S.; SALAMA, N.N. Ratio derivative spectrophotometric method for the determination of some oxicams in presence of their alkaline degradation products. Sci. Pharm., v.71, n.4, p.303-320, 2003.
TAHA, E.A.; SALAMA, N.N.; ABDEL FATTAH, EL-S. Stability-indicating chromatographic methods for the determination of some oxicams. J. AOAC Int., v.87, n.2, p.366-373, 2004

TAHA, E.A.; SALAMA, N.N.; ABDEL, F.; LAILA, S. Stability-indicating methods for determination of meloxicam and tenoxicam in the presence of their degradation products. Spectrosc. Lett. v.35, n.4, p.501$516,2002$.

TRACQUI, A.; KINTZ, P.; MANGIN, P. Systematic toxicological analysis using HPLC/DAD. J. Forensic Sci., v.40, n.2, p.254-262, 1995.

UNITED States Pharmacopeia. 28. ed. Rockville: United States Pharmacopeial Convention, 2005. p. 2748-2751.

YENER, G.; TOPALOGLU, Y.A spectrophotometric method for the determination of tenoxicam in tablets. Sci. Pharm., v.60, n.4, p.247-248, 1992.

Recebido para publicação em 18 de outubro de 2006. Aceito para publicação em 26 de novembro de 2007. 